\title{
IAMJ
}

INTERNATIONAL

AYURVEDIC

MEDICAL JOURNAL

\section{STUDY OF GIT RELATED KOSHTHANGA W.S.R. TO PAKWASHAYA}

\section{Pallavi Gupta ${ }^{1}$, Divya Nidhi}

${ }^{1}$ P.G. Scholar, Dept. of Rachana Sharir, State Ayurvedic College and Hospital, Lucknow, Uttar Pradesh, India ${ }^{2}$ Lecturer, Department of Rachana Sharir, State Ayurvedic College and Hospital, Lucknow Uttar Pradesh, India

Corresponding Author: Pallavig1947@gmail.com

\section{https://doi.org/10.46607/iamj2209072021}

(Published Online: July 2021)

Open Access

(C) International Ayurvedic Medical Journal, India 2021

Article Received: 22/06//2021 - Peer Reviewed: 24/06/2021 - Accepted for Publication: 26/06/2021

\section{Check for updates}

\section{ABSTRACT}

Human anatomy is the science where human body structures are designed to enable complete physiological action thus establishing homeostasis of the human body. Acharya Sushruta had a keen observation about the human body reflecting that without the absolute knowledge of Rachana Sharir. Chikitsak cannot be considered an expert. In Ayurveda, the part of G.I.T. is mentioned in Koshthanga by various Acharya. These Koshthanga are Aamashaya, Pakwashaya, Purishdhara, Uttarguda, Adharguda, Kshudrantra etc. which are situated within the koshtha. In modern anatomy, G.I.T. or Alimentary canal includes all the structures between the mouth and anus, forming a continuous passageway that includes the main organ of digestion, namely the stomach small intestine and large intestine, each part of the Gastric intestinal tract is adapted to its specific function. The 'oesophagus' function primarily to conduct food rapidly from the pharynx to the stomach mixing along with the digestive juices, carrying out partial digestion and then propelling the food into the duodenum is the function of the stomach small intestine is designed for complete digestion and absorption of nutrients. Absorption of water and electrolyte from the chyme to form solid faeces is the function of the large intestine. Pakwashaya is the main organ related to the site of Vata Dosha, Purishvaha srotas, Purishdhara kala, Koshthanga and Aashaya. Pakwashaya plays an important role in formation of urine and digestion of food.

Keywords: Pakwashaya, Purish 


\section{INTRODUCTION}

'Koshtha' means any one of the viscera of body. According to Charka, Koshtha is called Mahasrotas, sharir madhya mahanimna and Amapakwashaya term Mahasrotas is classified as the large tract extending from mouth to anus by Gananathsen, sharir madhya is define as Antaradhi i.e. part from jatru to kati by Indu. According to Vagbhatta, Mahanimna is the tract where food traverses to meet for digestion and absorption. 'Ama Pakwashaya' relates to the tract extending from Amashaya to Pakwashaya. The body cavity concerning the site of Ama, Agni, Pakwa, Mutra, Rudhir, Hrit, Unduk and Phupphusa is known as Koshtha. Achaea Charka has been described fifteen koshthanga situated within the kushtha i.e. Amashaya, Pakwashaya, Uttarguda, Adharguda, Pureeshadhara, Kshudrantra, Sthulantra, Yakrit and Pleeha etc.

Chakrapani has clarified that uttarguda is the koshthanga where pureesh stays and through which pureesh comes out in carried down Adharguda. Damodar Sharma Gaur has correlated the koshthanga with modern anatomy i.e. pureeshdhara as the caecum, Amashaya as stomach, Pakwashaya as the small intestine, uttarguda- an upper segment of the rectum, Adharguda - A lower segment of the rectum, Kshudrantra as Appendix and sthaulantra as the colon etc. Pakwashaya is the organ mentioned by various Acharya's in different text having various anatomical and physiological functions. It is the main organ related to the site of Vata Dosha. Pakwashaya plays an important role in the formation of urine and digestion of food. It also has clinical importance as the main site of vata dosha and the procedure of Basti. It has anatomical importance as many organs mentioned in Samhita concerning Pakwashaya so knowing the exact position of this organ, will help to understand related surface anatomy which will help in the surgical and para-surgical procedure. So, exploration of this organ is essential to understand anatomy and physiology. Acharya Charka gives many terms regarding the intestine they are Pakwashaya Sthulantra, Kshudrantra, Purishdhara Uttarguda and Adharguda. Pakwashaya is the matruj organ Pakwashaya include in Koshthanga by Charka, Kashyap and Sushruta. It is Moolsthana of Purishdhara srotas Brihdantra, Malashaya and Sthoolantra Pakwashaya are synonyms. Pakwashaya is located below Pittashaya and Aamashaya according to Charka. Concerning Shroni (Pelvis), Guda and Nabhi. The upper part of shroni and Guda below Nabhi according to Sushruta. Acharya Charka and Sushruta both described Pakwashayas as the Moolsthan of Purishvaha srotas. Process of formation of Purish and its' transport done through Pakwashaya. According to Sushruta, Pittadhara Kala is a place of the digestive system where the breakdown of food and water take place. It holds the food which is carried from Aamashaya and transfer that food to Pakwashaya, so it lies between Aamashaya and Pakwashaya. Complete separation of digested food into mala and Prasdabhaga present in Pakwashaya. Ashaya means Adhisthan, the place where Dosh, Dhatu or Mala are placed. After complete process digestion. Ahararasa, which is initially, taken, is converted into Pakwashaya, which is termed as Purish or Mala and its supporting organ is mentioned by word Pakwa, Here the word Pakwa is used for Pakwashaya as this Pakwaana stored in that thus Pakwashaya is the Ashaya or Adhisthan where Pakwa Anna i.e. Mala is store.

\section{DISCUSSION}

Pakwashaya is an organ included in Koshthanga by Acharya Charka and Sushruta., Acharya Vagbhatta mention whole Antra as a Koshthanga., Pakwashaya is in relation with Aamashaya, Nabhi, Shroni, Guda. All these organs are placed in the abdominal cavity, so it is clear that pakwashaya is the organ placed in the abdominal cavity. Charak and Dalhana mentioned Pakwashaya is situated below pittashaya by Charak below Aamashaya. Acharya Sushruta placed pakwashaya concerning Shroni and Guda as per Vagbhata Nabhi place in the centre of the Pakwashaya. While comparing the surface anatomy of the pakwashaya it is connected with the superior surface of the urinary bladder and the posterior surface of the uterus as mentioned by the Acharya. 
Pakwashaya is also related to the digestion of the food and form of faeces Pakwashaya involve in the formation of urine by absorption of water as per Ayurveda. The large intestine is having important role absorption of water. It also absorbs electrolyte, organic substance alcohol. It starts in the right iliac region of the pelvis, just at or below the right waist, where it is joined to the bottom end of the small intestine (caecum) from where it continues up the abdomen (ascending colon), then across the width of the abdominal cavity, and then it terms down continuing to its endpoint at the anus. The large intestine is about $1.5 \mathrm{mt}$. long. The overall function of the large intestine attributes to the completion of absorption the manufacture of certain vitamins, the formation of faeces and the expulsion of faeces from the body.

\section{CONCLUSION}

Pakwashaya is an organ situated in the abdominal cavity. In modern anatomical structure, Pakwashaya is a present entire part of the large intestine i.e. from the caecum to the rectum. Physiologically Pakwashaya is the main organ having the function of absorbing a large amount of water.

\section{REFERENCES}

1. Vidyotini Teeka, Charak Samhita Sutrasthan, Chapter11, verse-48, 2008, page-235.

2. Vidyotini Teeka, Charak Samhita Sharirsthan, Chapter-07, verse-10, 2008, page-913.

3. D.S. Gaur parishadyam, Shabdarth Shariram, Vaidyanath Ayurveda Bhawan, 0979, Page 50.

4. Ambikadutta Shastri, Sushruta Samhita of Sushruta Chikitsthan, Chapter-02, verse $12,13^{\text {th }}$ edition, Chaukhambha Sanskrit Sansthan, 2009, page 19.

5. Ambikadutta Shastri, Sushruta Samhita of Sushruta Chikitsthan, Chapter-02, verse $6,13^{\text {th }}$ edition, Chaukhambha Sanskrit Sansthan, 2009, page 113.

6. Thesis Dr Sunita Kumari "A Critical Study of Annavaha Srotas with special reference to Pittadhara kala" 2004, page. - 36

\section{Source of Support: Nil \\ Conflict of Interest: None Declared}

How to cite this URL: Pallavi Gupta \& Divya Nidhi: Study Of GIT Related Koshthanga W.S.R. To Pakwashaya. International Ayurvedic Medical Journal \{online\} 2021 \{cited July 2021\} Available from: http://www.iamj.in/posts/images/upload/1466_1468.pdf 